\title{
Sustainable Library Buildings: Green Design Needs and Interior Architecture Students' Ideas for Special Collection Rooms
}

\author{
Yasemin Afacan \\ Department of Interior Architecture \& Environmental Design, Faculty of Art, Design and Architecture, Bilkent University, TR-06800 Bilkent, Ankara, Turkey
}

\section{Introduction}

The growing concern about and increasing interest in sustainable built environments is changing the agenda of academic libraries. An academic library is defined as a library attached to a higher education institution for two complementary purposes: to support the school's curricula and to support the research of faculty and students (Curzon \& Quinonez-Skinner, 2009). Thus, academic libraries serve as the core of the three 'E's of the future: economy, ecology and equity (Jankowska \& Marcum, 2010). These three dynamics are also key issues in sustainability, which must ensure the occupants' safety, health, comfort and satisfaction, 'while meeting the needs of the present without compromising the ability of future generations to meet their own needs' (United Nations Brundtland Commission, 1987, 41). Now and for the future, sustainable design must be part of library operations, collection developments and service provision (Jankowska \& Marcum, 2010). In this context, most recent researchers are identifying a variety of factors that threaten the sustainability of academic libraries: How can academic libraries continue to grow while minimising their impact on the environment? Since special collections and archives are at the heart of academic libraries, researchers are concerned with this question in regard to strict climate-control requirements for collection preservation. Moreover, making those collections available in an equitable way, supplying unique materials for all, supporting their documents digitally and maintaining indoor air quality within the framework of sustainable strategies differentiate special collections spaces from other library spaces. This paper addresses these challenges through a user-centered design approach based on three stages. First, user needs were elucidated through an importance-assessment questionnaire given to 240 interior architecture student participants. Second, the participants were asked on a volunteer basis to develop architectural solutions for the special collection at Bilkent University Library based on sustainable design principles. In the last stage, the solution alternatives were assessed and systematised to identify key green design attributes for special collections.

\section{Literature review}

Since the United Nations' Brundtland Commission (1987) and the
1992 Rio Earth Summit, which put human beings at the center of the concern for sustainable development and outlined the goal for humans to live healthy and productive lives in harmony with nature (Birkeland, 2002), the concept of sustainability has become an overarching principle in many national and international studies. Sustainable buildings provide environmentally friendly and energy-efficient design by implementing a holistic approach to decrease negative impacts on users and the environment (Ali \& Al Nsairat, 2009). It is an undeniable fact that the built environment is one of the main factors in global energy consumption (Luther \& Rajagopalan, 2014; Zhao, He, Johnson, \& Mou, 2015). In this respect, greening current building stocks is crucial because sustainable green renovation (and construction) decrease energy consumption by reducing environmental pollution, maintenance and transportation costs, as well as material waste (Douglas, 2006). In fact, as academic institutions, universities have a special place in this environment because campuses consist of buildings with complex functions, such as laboratories, lecture halls, sports facilities, libraries and accommodation units, among others (Sesana, Grecchi, Salvalai,\& Rasica, 2016). As key buildings on campus, libraries can be a role model for sustainable practices, showcasing green building methods and raising awareness regarding sustainability (Hardesty, 2011). According to Shane (2012), a thoughtfully designed green library informs the community about environmental efficiency and motivates them to visit other green projects (and possibly even inspires them to build a green project themselves). However, constructing a new green library or greening an existing library building involves a complex and demanding decision-making process due to its multi-dimensional nature.

In 1989, there was a significant effort by the Social Responsibilities Round Table of the American Library Association to develop environmentally sustainable practices for academic libraries (Antonelli$\&$ McCullough, 2012). Since 1990, library literature on sustainability has also grown, with a focus on green library operations and practices. Sustainability has become a driving force in today's library design, and there are many examples of sustainable academic libraries around the world (Edward, 2011). International and national sustainable rating systems and certificates are gaining recognition and bring attention to sustainable academic libraries (Hardesty, 2011). The George R. White Library and Learning Center at Concordia University in Montreal, the Littauer Fine Arts Library at Harvard University, Library West at the

E-mail address: yasemine@bilkent.edu.tr. 
University of Florida and the Special Collections Library at the University of South Carolina are examples of academic library buildings with the Leadership in Energy and Environmental Design (LEED) certificate, which is one of the most popular green building certification programs worldwide (Hardesty, 2011; US Green Building Council, 2014). The Hive Worcester Library at the University of Worcester and the Library of Birmingham University have been redesigned as the green heart of their respective campuses and hold a Building Research Establishment Environmental Assessment Method (BREEAM) certificate, a program launched by the UK as a cost-effective sustainability assessment method (BREEAM, 2014). Macquarie University Library (Brodie, 2012) and the Library at Dock (Green Building Council Australia, 2014) are academic library examples with a Green Star certificate, which is a sustainability rating system used in Australia. In Turkey, Özyeğin University (including its library building) was the first (and is still the only) green campus with a LEED certificate in Turkey (US Green Building Council, 2014).

\section{Challenges of a green library and sustainable special collection rooms}

Brodie (2012) explored a number of current issues and challenges in building sustainable libraries based on energy-efficient and holistic relationships among strategy, structure, people and operations. These relationships in the literature are explained through the concept of 'ecological footprinting' for library design and management alike (Chowdhury, 2010; Sanders, 2002; Shane, 2012; Weiner \& Boyden, 2001). Chowdhury's (2010) research on the carbon footprint of the knowledge industry explores the electronic future of books, which is more sustainable than print, an important factor for libraries. Of course, knowledge in electronic format and digital services as sustainable practices are commonly used around the world (Antonelli, 2008). Moreover, a number of studies on the architectural design strategies suggested, developed and applied to reduce energy consumption and create a healthier and more enjoyable library environment. They emphasise using renewable energy sources (solar energy, daylighting, etc.), water management with rainwater harvesting and water recycling, using ecological materials and innovative technologies for construction and management, creating a comfortable indoor environmental quality (thermal comfort, acoustics and air quality) and the green character of the library neighborhood in terms of landscape and proximity to public transportation (Birkeland, 2002; Edward, 2011; Kilic \& Hasirci, 2011; Shane, 2012). Green libraries should be energy and water efficient, use ecological and non-toxic materials and furniture and reduce maintenance costs through recycling and reusing (Jankowska \& Marcum, 2010). The Libris Design project is an important example of providing design solutions for library acoustics, interior materials and technology infrastructure (Sands, 2007). Achieving a sustainable library requires a mutual relationship between digital services and the above-defined architectural design strategies in planning, implementation and management. However, merely implementing sustainable practices does not guarantee green success; architects and designers should ensure users' satisfaction by soliciting their needs and preferences before building new libraries or refurbishing existing ones.

A library literature review reveals a scarcity of sustainable strategies as well as user-involvement. DeClercq and Cranz (2014) surveyed architecture students in the design process of an academic library, but their study was focused on traffic flow and human-factor implications rather than sustainability based on green standards. Recent studies in the US, UK and Europe raise a major concern regarding the difficulty of sustaining digital information that requires electronic equipment to access and use. Although digital services create the opportunity to access knowledge without actually visiting a library, the importance of the library as a physical setting is diminishing (Michnik, 2015), and it is difficult now to define a library as a social interaction space. The difficulty in terms of the sustainability perspective has three aspects: (i) digital services use electronic equipment, which requires more energy than books to create and use and which produces heat and contains toxic materials that threaten human health; (ii) collections' physical layouts are at risk of empty shelves, which impacts the architectural quality of the library space; and (iii) changes in digital services affects the storage and dissemination of archival documents in special collections (e.g. tapes to discs to digitised information) (Aabø, 2005; Michnik, 2015).

A current literature review on special collections also reveals a dearth of sustainable strategies and some user-involvement issues. Special collections in academic libraries are like treasure chests, housing rare books, manuscripts, photographs, archives and digital records (Cave, 1982). Unique and rare are the key words for items in special collections; they should not only contain books, but also maps, visual image collections, personal papers and historical interviews (Little, 2012). In this respect, special collections are important aspects of higher education in terms of being primary sources, which offer students the opportunity to analyse and synthesise knowledge and enable them to acquire information through different learning styles. According to Blouin (2010), special collections are a point of mediation, which means that they act as a place of connection rather than as a repository. Thus, assessing user needs and sustaining the physical and social relationship between user needs and rare, unique and special documents becomes essential. A building with poor environmental qualities (acoustics, lighting, ventilation, etc.) can generate discomfort and dissatisfaction among users (Brown, Cole, Robinson,\& Dowlatabadi, 2010), and thus decrease visits.

The physical and social value of special collections as primary sources of knowledge is obvious. However, there is little or no research on their sustainable development from the undergraduate student perspective. According to Pearson (2010), special collections raise concerns about management through digital practices, and can result in conflict between traditional digital ways of doing things. Little (2012) investigates the use of technology in special collections and categorises them into two groups: analog special collections, consisting of items documented using mobile devices and cameras, and digital special collections, with items documented using digital materials. Either way, it is still hard to manage and preserve such materials sustainably.

Considering the above factors, what are the needs of, demands and importance levels for undergraduate students using special collections? How could an existing special collection room in an academic library be architecturally reworked around sustainable design strategies? These questions play significant roles in this study. According to Brown et al. (2010), financial considerations and informing users about the green design process is essential for successful long-term building operations. It should be noted, however, that the current study does not focus on sustainable processes, procedures and workflows regarding digitising materials in a special collection; rather it is concerned with interior design solution alternatives regarding energy efficiency, comfortable spatial layout for shelves and study areas, satisfactory indoor environmental quality (daylight, air comfort, heating and cooling, etc.) and green materials.

\section{A user-centered design approach model}

Researchers have not agreed on a single definition for user-centered design. While Barki and Hartwick (1989: 53) explain it as a 'subjective psychological state reflecting the importance and personal relevance of a system to the user', Ives and Olson (1984) consider it the involvement of end users into a design process. Kujala (2003) offers a broader explanation, encompassing all approaches that have a direct connection with the users. For designers, identifying user needs and requirements is essential, and acquiring knowledge about users' potential needs is only possible by involving the user in the design development (Duverger, 2012) and observing and/or predicting his or her participation in the design (Kujala, 2003). Involving the user increases user satisfaction and 
Table 1

Three-stages user-centered design approach model.

\begin{tabular}{|c|c|c|c|}
\hline Stages & Methods & Obtained data & $\begin{array}{l}\text { Participant size } \\
\mathrm{N}=\end{array}$ \\
\hline First stage & $\begin{array}{l}\text { Informative level of UCD: } \\
\text { - 46-Item survey }\end{array}$ & $\begin{array}{l}\text { Green needs and importance levels of undergraduate students regarding a sustainable } \\
\text { special collection room in general. }\end{array}$ & 240 \\
\hline Second stage & $\begin{array}{l}\text { Consultative and participative level of UCD: } \\
\text { - Walkthrough visits (photographs, user observations } \\
\text { and staff interviews) } \\
\text { - Design process } \\
\text { (drawings and models) }\end{array}$ & $\begin{array}{l}\text { The architectural solution alternatives for the special collection at Bilkent University } \\
\text { Library based on the sustainable design principles. } \\
\text { - 2-D drawings and a model of } 1 / 20 \text { scale }\end{array}$ & $120-30$ projects \\
\hline \multirow[t]{2}{*}{ Third stage } & Jury evaluation & - Key green design attributes for special collections. & $120-30$ projects \\
\hline & & & 5 jury members \\
\hline
\end{tabular}

experiences and provides more beneficial, suitable and acceptable design results (Duverger, 2012; Kujala, 2003). After designers gather data (user needs and requirements), they interpret this information to use as design criteria, inspiration and/or innovation (Sanders, 2002). As the design process is a joint undertaking with designers, stakeholders and end users, omitting one or more of these actors can result in a failed design.

Sometimes designers avoid user-centered design approaches because they find their implementations difficult and time consuming (Mao, Vredenburg, Smith, \& Carey, 2005). Further, there is an opinion that users' preferences are often conservative, opposing innovation and creativity, and that users have difficulty picturing the final outcome (Barki \& Hartwick, 1989). However, these opinions and perceived challenges may arise from designers not establishing a close enough relationship with users (Kujala, 2003). Cooperation between users and the design team, rather than a research group investigating user needs and requirements, is highly advisable; a direct connection with users is more valuable than reading or hearing information about their needs (Gould \& Lewis, 1985). Collaboration between users and designers should occur from beginning to end of the design process (Olsson, 2004). Damodaran (1996) explains that a user-centered design approach can have three levels of intensity: informative, consultative and participative. At the informative level, users are considered only as a source of information. This kind of involvement is preferable only when indirect user participation in the process is desired (Olsson, 2004). At the consultative level, users contribute directly to the design process (Kujala, 2003). At the participative level, user involvement shapes all phases of the design process; from decision-making to final output (Damodaran, 1996). Regardless of the level of user involvement, it is important to evoke a sense of collaboration; when users consider them part of design process, they use and understand the design more (Barki \& Hartwick, 1989). Since academic libraries have become more user focused (Andaleed \& Simmonds, 1998), a user-centered design model is essential.

\section{Methodology}

\section{Participants and the case special collection}

The current study included 240 undergraduate students (130 in third year and 110 in fourth year) from the Department of Interior Architecture and Environmental Design at Bilkent University in Ankara, Turkey. The students had a mean age of 21.05 years, and 47 of them were male and 193 were female. The Halil Inalcik Special Collection Room at Bilkent University Library is the case location. Bilkent University Library is not a green library and the Halil Inalcik Special Collection does not have sustainable design features; however, as part of the university's goal to become a world-class sustainable campus, it has a vision of an ecologically and socially sustainable library. Bilkent University has already started to digitise books, journals and off-prints based on the International Federation of Library Associations and
Institutions' (IFLA) Guidelines for Planning the Digitization of Rare Book and Manuscript Collections (IFLA, 2014). According to Turkey's Regulation of Energy Performance in Buildings (2008), in compliance with the Kyoto Protocol by the country's Ministry of Energy and Natural Resources, each building in Turkey will require an Energy Identification Certificate by the end of 2017, which means that understanding and implementing the green building concept is key in the building and public sector in Turkey.

Built in 1987, Bilkent University Library offers $13,275 \mathrm{~m}^{2}$ of usage areas, and is one of the most-frequented buildings on campus; in 2015, approximately 770,845 university students used the library building (Bilkent University Library, 2016). In 1993, Halil İnalcık, a professor of Ottoman history, donated his valuable collection to Bilkent and it is now housed in a special room in the library (Bilkent University Library, 2016). The collection includes a total of 13,000 books, journals and offprints on the history of Ottoman Empire in many languages (including Ottoman and modern Turkish, Persian, Arabic, English, French, Italian and German).

\section{Procedure}

This study is based on the user-centered design approach model, which is composed of three stages (Table 1). In the first two stages, the study employed the three levels of a user-centered design approach discussed above. In the first stage, the informative level of user involvement was achieved through a three-section survey. The first section collected demographic data and in the second section, participants were asked about their usage pattern of the special collection room and how they understand the term green. For the third part of the survey, the author developed a 46-item questionnaire based on a five-point Likert-scale ( 1 for the least important and 5 for the most important) to investigate the green suggestions and needs of undergraduate students regarding a sustainable special collection room in general. Each statement in the survey was formed considering the LEED, 2009 requirements for Existing Building Operations and Maintenance and Turkey's Energy Performance of Building Regulations and then relating them to library users' needs.

In the second stage of the survey, participants were asked on a volunteer basis to develop architectural solutions for the Halil İnalcık special collection based on sustainable design principles. In total, 120 students (80 from third year and 40 students from fourth year) participated in the design process. Users were consulted and participated through redesign suggestions. Before the second stage, walkthrough visits were conducted in groups of 10 for students, who volunteered for the redesign project, to understand the room's current layout and design and to collect visual and verbal data (photographs, observations and interviews with the librarians responsible for the room). The objective of this stage was to let the students analyse, synthesise and evaluate sustainable design strategies to create their own design solutions. To assist in the design process, the room's architectural plan was distributed to students in print and digital forms. Students worked in 
Table 2

Summary of the rotated factors.

\begin{tabular}{llllll}
\hline Factor & Scale & Eigenvalue & Variance (\%) & Cumulative (\%) & Means \\
\hline 1 & $\begin{array}{l}\text { Energy-efficient } \\
\text { lighting }\end{array}$ & 16.903 & 33.806 & 33.806 & 4.011 \\
2 & $\begin{array}{l}\text { Improved indoor } \\
\text { air quality } \\
\text { Adequate } \\
\text { thermal comfort }\end{array}$ & 3.343 & 6.936 & 40,502 & 4.333 \\
4 & $\begin{array}{l}\text { Technology } \\
\text { usage }\end{array}$ & 1.598 & 3.873 & 44.570 & 4.054 \\
\hline
\end{tabular}

groups of four and were asked to include digital storage and/or exhibition options that promoted sustainable features for the collection.

Students' goals were twofold: (i) design the special collection environment for all library users and the university as a whole to serve as a cultural heritage center, and (ii) relate it to a sustainability aspect, that is, sustaining cultural heritage collections. The redesigned special collection room needed to include: (i) collection shelves for rare books, manuscripts, photographs and archives; (ii) a reading/working area; (iii) an office area for the donor; (iv) an exhibition area/units and (v) digital shelving systems. Other requirements included adequate indoor air quality in terms of temperature, humidity and lighting; a self- contained energy source (e.g. solar or wind power); ecological and natural materials; state-of-the-art waste production or emissions techniques, products and systems; sustainable furniture ideas and sustainable interior space ideas. In total, 30 projects were submitted. The final stage was the jury evaluations of the projects, which included architectural drawings of the plan, section and perspectives and a 3-D model on a 1/ 20 scale. The jury was composed of the author, the two librarians interviewed by the students in the second stage and two LEED-certified associate interior architects.

\section{Results}

All students' ratings of the 46 items were analysed with the statistical package for the social sciences (SPSS 21.0), and then frequency distributions were calculated. The alpha coefficient for all items was 0.967 , suggesting that there is a relatively high internal consistency. The author also conducted exploratory factor analyses to investigate correlated variables of green needs. Because a ratio as low as five subjects per variable is appropriate for distribution (Bentler \& Chou, 1987), the study sample size can be considered adequate in terms of sample representativeness and estimation accuracy. The survey has an internal consistency of 0.958 (Cronbach's alpha value). According to Nunnally (1978), a survey indicates a high level of reliability if this value is above 0.7. Through the Varimax method, a frequently used rotation option (Argyrous, 2005), the author constructed a rotated component matrix to identify the number of factors among the set of correlations within the obtained data. Factor analysis examined the interrelationships among green needs and the importance levels of undergraduate students regarding a sustainable special collection room in general.

\section{Survey results}

According to the descriptive analysis, most participants (167 of 240) considered a green special collection room in a library as 'a special collection room that is healthy and comfortable'. Forty-eight students defined a green special collection room as a room that is energy/water/ thermal saving. Twenty students defined such a room as space that is material saving with digital technology. Only five students considered that the meaning of a green special collection room might be something else, such as a comfortable reading room with daylight intake. Regarding the familiarity issue, while the majority of students stated that they were very familiar (153 out of 240) or somewhat familiar (48 out of 240) with the Halil Inalc1k Special Collection in Bilkent Library, the remaining students defined themselves as not very familiar (28 out of 240) and not familiar (11 out of 240) with the collection. Among 201 familiar students, only 30 students had used materials from the special collection either once a semester (12 out of 30) or once a year (18 out of 30 ). The rest of the students had not used any material from the room. The usage purpose was mainly based on course requirements (22 out of 30 ) or personal study (8 out of 30). Finally, according to 145 students, 'sustaining physical and social relationships between users and rare documents' is the most important goal of a green special collection, and 130 of these 145 students also defined 'managing and preserving the digital materials in a sustainable way' as the second most important goal of a green special collection. Interestingly, 60 students rated both 'providing better ventilation and lighting conditions for indoor environments' and 'helping to access primary sources digitally' as important. Twenty-two students found 'helping to save energy' as the least important goal of the special collection, and 10 students rated 'helping to protect the environment and reduce pollution' as the least important goal. No rated the importance item of 'helping to reduce the amount of construction material used'.

According to the exploratory factor analysis, four green factors were identified with $47.765 \%$ variances (Table 2). Factor 1, 'energy-efficient lighting' has seven components related to daylight and artificial lighting issues (see Appendix A). A commercial building uses $41 \%$ of its energy on illumination, thus, according to LEED standards, a green building should supply at least 75\% of its lighting needs (LEED, 2009). The first four components of Factor 1 are related to efficient artificial lighting elements in both study and circulation areas, and the last three components highlight the importance of daylight in study areas and daylight control strategies, such as blinds and curtains, to prevent glare and visual discomfort. Although organically based items such as cloth, carpets, leather, watercolors, drawings, and manuscripts are highly sensitive to short-wavelength radiation such as ultraviolet and infrared beams, daylight in a library and special collection rooms should be part of a sustainable management strategy (Bougdah \& Sharples, 2009). According to Shane (2012), even in underground sections of a library daylight intake may be possible by creating a section for a skylight and/ or light well. Among the components of Factor 1, the item 'adequate daylight in study areas' was rated as the most important item (mean $=4.22$ ) in the current study, a result consistent with the literature. The benefits of daylight, in addition to decreased costs and increased visual comfort are closely associated with user pleasantness, satisfaction, concentration and focus in study areas (Bougdah\& Sharples, 2009).

Factor 2 is defined as 'improved indoor air quality' and has five components (see Appendix A), among which adequate natural and mechanical ventilation had the highest mean values (mean $=4.41$ ). This finding is also consistent with the literature, which explains that proper airflow through the envelope of a building is essential for user health, productivity and comfort (Edward, 2011). Temperature, humidity and carbon dioxide levels are indicators of indoor air quality (ASHRAE 55, 2004), and changes to healthy levels of these indicators can result in illness and decreased work performance. Moreover, for improved indoor air quality, survey participants also rated the items of 'usage of non-toxic free materials' and 'cleanliness of the room' as important.

Factor 3 is 'adequate thermal comfort' and had the following four components: (1) even heat distribution within the room; (ii) heating systems providing adequate thermal comfort for occupants; (iii) cooling systems providing adequate thermal comfort for occupants and (iv) efficiency of thermal insulation. As stated in the literature (Edward, 2011), Factors 1, 2 and 3 are highly associated with each other as they work together to achieve optimal indoor environmental qualities. Ensuring healthy air quality and a comfortable thermal environment involves design strategies that manipulate the building's shape, form, 


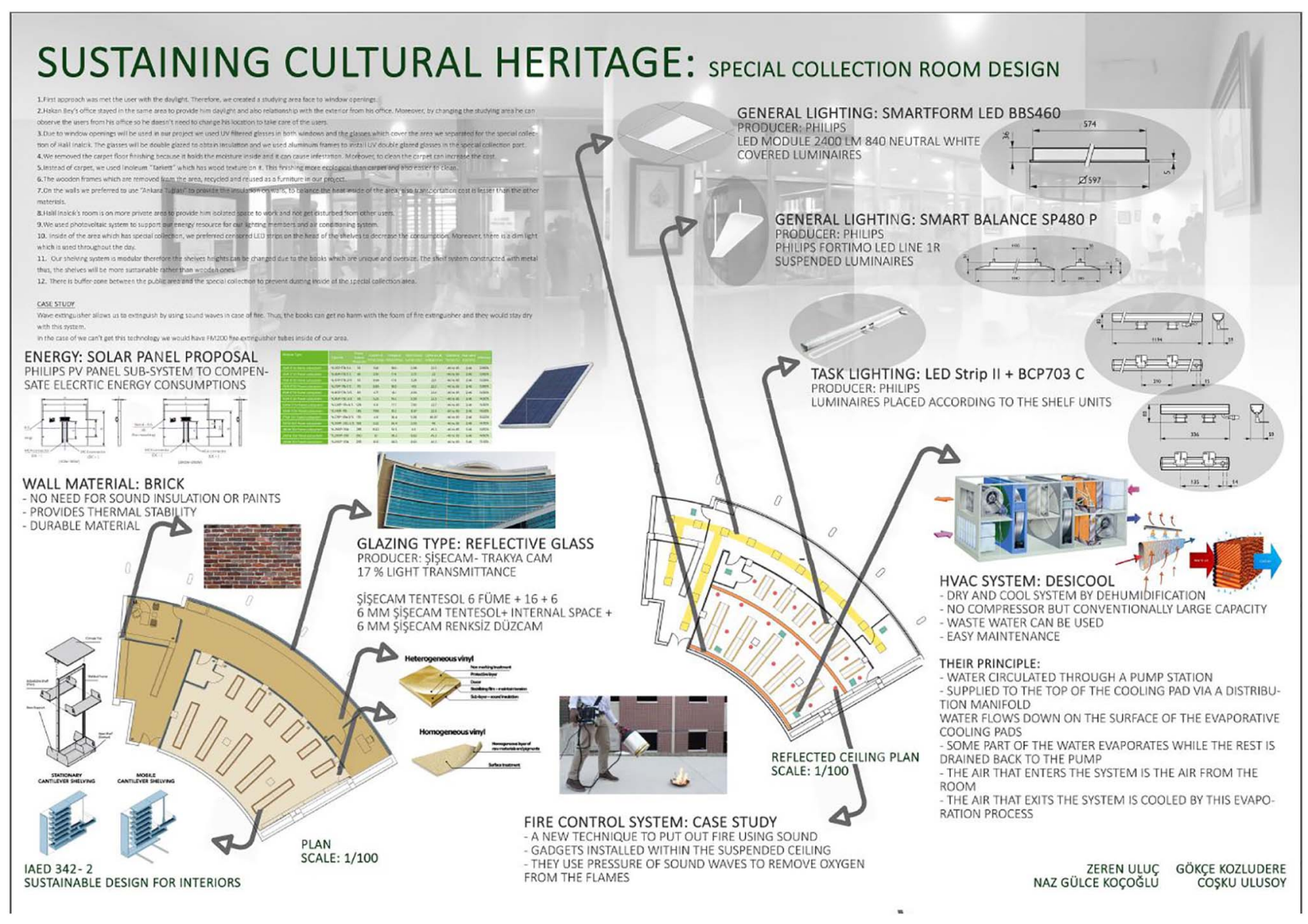

Fig. 1. An exemplary student group project regarding indoor environmental quality.

orientation and envelope to benefit from natural energy from the sun, wind and outside conditions (Bougdah \& Sharples, 2009). In this respect, considering the mutual relationship of the three factors, using the sun's heat through glazing it is possible to eliminate the need for mechanical heating to warm interiors, while solar shading in the form of wide overhangs and louvres contribute to natural cooling. Further, the amount and orientation of glazing can help ensure effective daylight and ventilation while controlling humidity and reducing the need for mechanical ventilation. Thus, designers of a green special collection room must simultaneously consider a set of criteria to maximise the collection's overall sustainability regarding diverse user needs and expectations.

Factor 4 concerns the role of technology. Participants highlighted the importance of taking advantage of new and emerging technologies to design special collections. For example, the availability of a virtual bookshelf, which is an online record of books a user has read or wants to read, was ranked as the most important item (mean $=4.77$ ). As students are not allowed to borrow books or any other material from the special collection room, this factor reflects the importance of the availability and effectiveness of technological devices to capably study the documents. Hence, there is a growing technology trend in special collections. Although the digitisation process in these collections is inevitable, it is a challenge because it requires careful consideration of image quality, order of metadata, conceptualisation and planning to minimise the potential of physical damage to the items (IFLA, 2014). Further, the metadata in some manuscripts and rare documents cannot be digitised, due to deterioration, type of data and other factors.

\section{Design process results}

As design is a heterogeneous process, students' approaches, sustainable perspectives and experiences they gained throughout their design education influenced each project. The 30 project proposals mainly focused on recycling, energy efficiency, indoor environmental quality (lighting, acoustics, thermal comfort and ventilation) and sustainable materials. Although it was stated in the problem definition that each project should consider technology usage, only five projects proposed digital storage and/or exhibition options that promoted sustainable features, and only in the form of adding high-technology computers and screens to the walls of the room. Rather than concentrating on technology equipment, it was hoped the projects would propose specific methods of digital capture or digital preservation to achieve desired outcomes and sustainable results. Thus, this aspect was the weakest part of the study's second stage.

Based on the jury's comments, the projects can be categorised into two sustainable-strategy groups, with the first strategy focusing on improving indoor environmental quality (lighting, thermal comfort, ventilation). As the primary challenge of the given problem for that stage was to transform the existing special collection room into a sustainable collection space while ensuring user health and comfort, most of the projects (27 out of 30 ) concentrated on efficient daylight intake through the existing windows. Ten projects proposed energy-efficient glazing, which reduces utility costs by $25 \%$. All projects (19 out of 30 ) that used daylight also proposed daylight-control strategies such as blinds, black curtains, light-directing louvres, movable shading systems and mirrored systems. Regarding artificial lighting, all projects suggested LED technology, efficient fluorescent lighting, daylight sensors in working areas and motion-sensor lights in shelving areas. Adequate thermal comfort was suggested in two ways: (i) complete replacement of the existing heating, ventilation and air-conditioning system (HVAC) with sustainable technologies, such as using a separate solar system for heating together with a variable-air-flow system for cooling and 
ventilation; and (ii) a mixed-mode HVAC system, which improved the existing heating and cooling system of mechanical ventilation and added natural ventilation solutions from mechanically or manually operated windows, louvres and dampers. Twelve projects proposed alternative fire control systems, such using sound waves with different pressures to remove oxygen from flames. Fig. 1 illustrates an exemplary student group project regarding indoor environmental quality.

The second strategy group used durable, renewable (linoleum, agriboard) and recycled materials (cellulose, carpeting) and products. Most of those projects (25 out of 30 ) sought the lowest possible environmental impact from the special collection by concentrating on low-/no-VOC (volatile organic compound) materials, which has no or few organic chemicals with a high vapor pressure at room temperature. Vinyl products were avoided by all projects. Half the projects (17 out of 30) preferred locally harvested and manufactured wood and stone. Moreover, modular and adaptable shelving systems were designed by 27 projects to offer maximum flexibility for displaying and storing the collection. Figs. 2 and 3 illustrate exemplary student group projects regarding the use of recycled materials and modular shelving.

\section{Green design strategies for special collections}

These study findings could be considered when retrofitting and/or constructing a green special collection to integrate sustainable design features. This study does not aim to repeat well-known standards and principles regarding sustainable library design, but rather to summarise the research findings in terms of practical guidelines and design attributes based on the survey and design-process results:

i. Adequate and energy-efficient artificial lighting, such as compact fluorescent lighting with fuller spectrum tubes, LED lighting, etc. is key for study areas.

ii. Daylight design elements (windows and skylights) should consider their size and location design and be combined with control strategies such as shading systems and daylight reflection and filtration techniques.

iii. Proper air quality is crucial for users' health and study performance.

iv. An ideal air circulation system is a mixed combination of natural ventilation, including operable windows, and the mechanical ventilation of integrated HVAC systems.

v. For enhanced environmental qualities, thermal comfort, temperature and humidity levels should be monitored, something also necessary for ensuring preservation of rare documents.

vi. In addition to cleanliness and maintenance of the collection, using non-toxic materials in walls, floors, ceilings, shelving, etc. should be considered.

vii. A special collection room should also consider the outside view. A design with a controlled outside view can motivate users and enhance interior environmental quality in terms of daylight, natural ventilation and thermal comfort.

viii. Availability of energy-efficient electrical office equipment (computers, photocopiers, printers, etc.) will help increase technology usage around special collections, but not enough so that it is a digital collection room. There should be ease of access to the collections and innovative web technologies to make items available and searchable to the online community of researchers.

ix. Building a good digital collection requires long-term sustainable processes, procedures and workflows to digitise the materials.

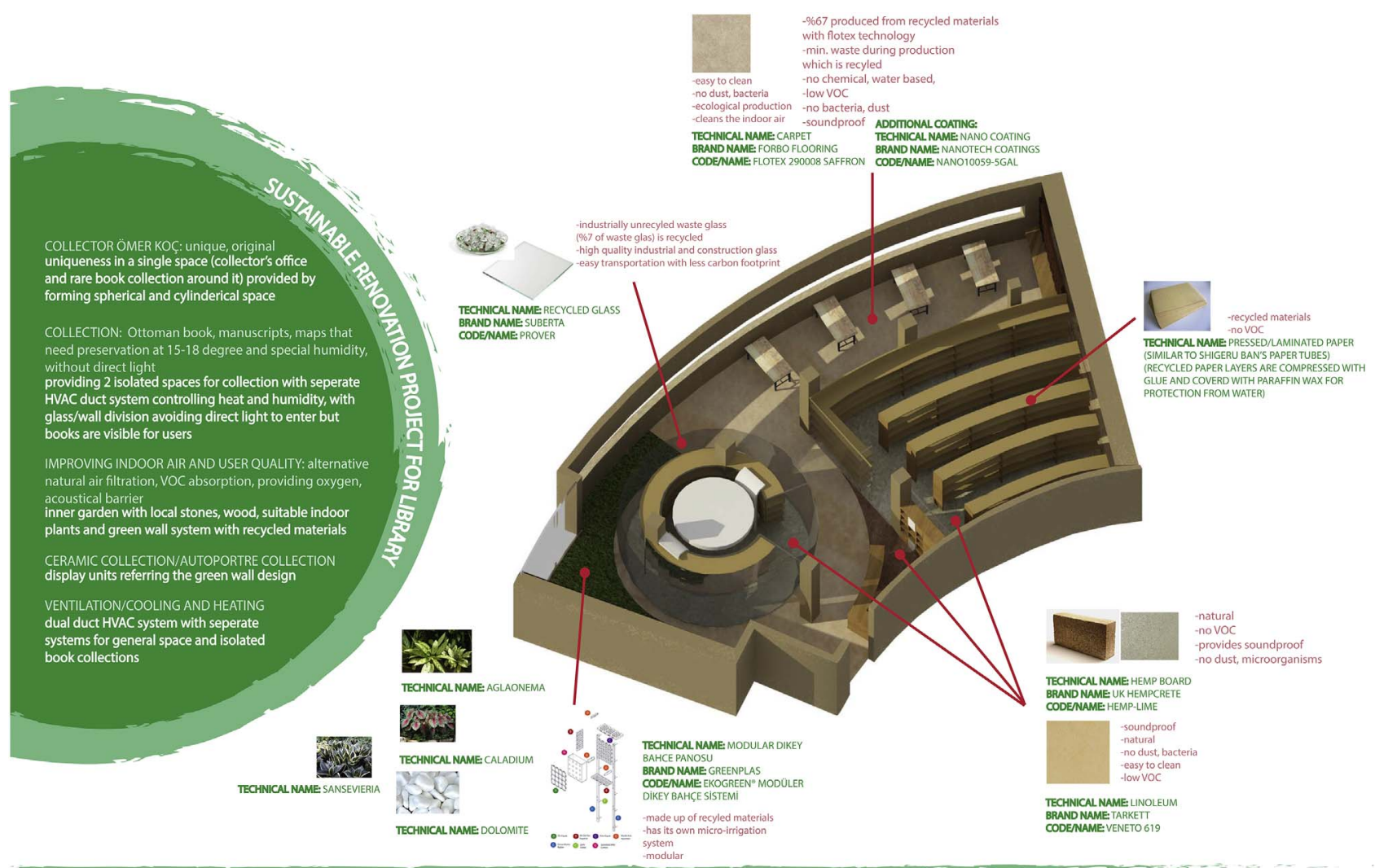

BII. KENT ONIVERSITESI GUZTL SANATI. AR, TASARIM VE MIMARLIK FAKOITISI, IC MIMARI IK VE CEVRE TASARIMI BOL UMO

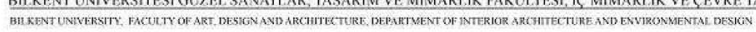

Fig. 2. An exemplary student group project regarding the usage of recycled materials. 


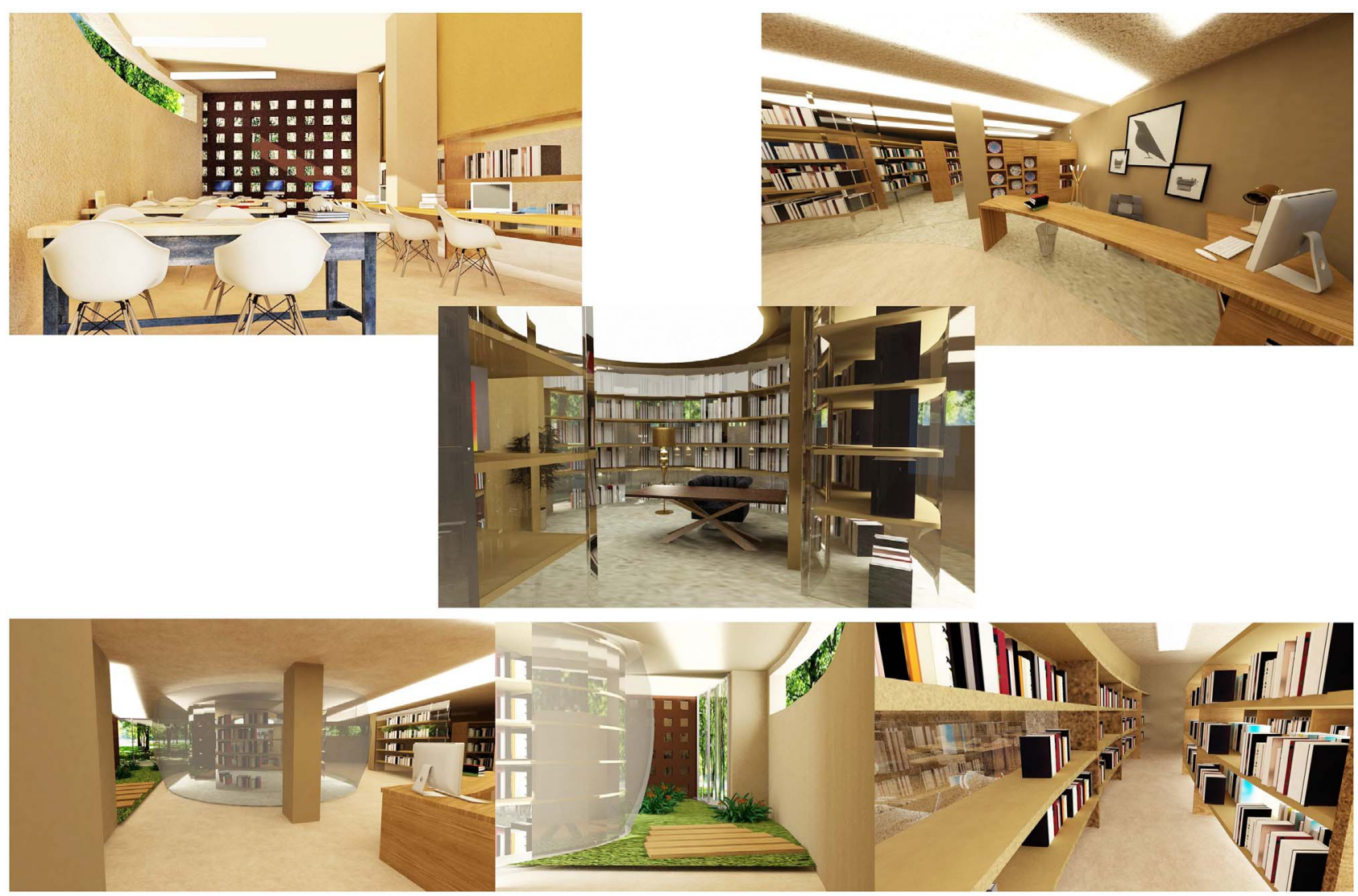

Fig. 3. An exemplary student group project regarding the usage of modular shelving.

\section{Conclusion}

Making special collections green increases energy efficiency and makes them healthier and more comfortable and aesthetically appealing. However, each special collection is unique and offers diverse challenges. Different than any other public area of a library, special collection are required to meet increasingly demanding architectural qualities with respect to comfort, security, accessibility and sustainability because of their exceptional nature and the need for safe and sensitive handling processes of rare materials, unique manuscripts and fragile books. Regarding their role in academic libraries, special collections are in a unique position to take advantage of sustainable design solutions. Considered together, the proposed student architectural solutions in this study are more appropriate for a special collections area than a regular library area for the following three reasons: First, special collection materials are often kept away from direct sunlight because of the possible physical damage from unstable temperatures and humidity. Thus, as suggested in the first factor, energy efficiency and the amount of daylight as a primary source of sustainable illumination for interior spaces are more important factors for special collections than for any other spaces in academic libraries. Second, as the special content of these rare materials must be preserved over the long term, air quality and indoor temperature must not threaten the uniqueness of these archives. Therefore, in the study areas of special collection rooms, designers, librarians and administrators should pay particular attention to pollution-free materials, moisture levels and ventilation controls, as well as to thermal comfort levels. Last, unlike other library materials, rare materials and any complex documents in special collections require greater care and special equipment when using technology to digitise and scan them. Such as the appropriate opening angle for books and the appropriate handling of fragile objects, humidifiers, book cradles, etc. (IFLA, 2014). Accordingly, retrofitting versus new construction is a big decision when the architectural and environmental roles of special collections are compared to other library spaces.

Making special collections and archival materials sustainable is vital to preserve collections for lifelong learning. In this respect, special collections should be also usable in the digital environment to ensure research value in the future. However, sustainable digitisation is more complex than concentrating on technology usage; it also requires increased efforts in design, planning and management. For these reasons, it is essential to collaborate with users conducting digital-based research to create sustainable and adaptable digital special collections.

This study is significant in terms of highlighting the importance of user involvement in green design processes. Discomfort and dissatisfaction currently perceived by users can be prevented through usercentered design models at the outset of library projects. Moreover, users' visit patterns and importance ratings are also of great importance regarding the environmental and social impacts of library buildings, especially special collections. In summary, this study reveals the significance and challenges of sustainable library renovations for special collections, and takes them a step further by advocating a user-centered design approach that encompasses more user-importance levels than energy and resource points. Such an approach can provide increased insights into sustainable special collection design, planning and administration, resulting in a greater likelihood of meeting users' needs, demands and expectations. 


\section{Appendix A. Factors and their loadings}

Table 1

Factor 1 'energy-efficient lighting' and its corresponding item with their loadings.

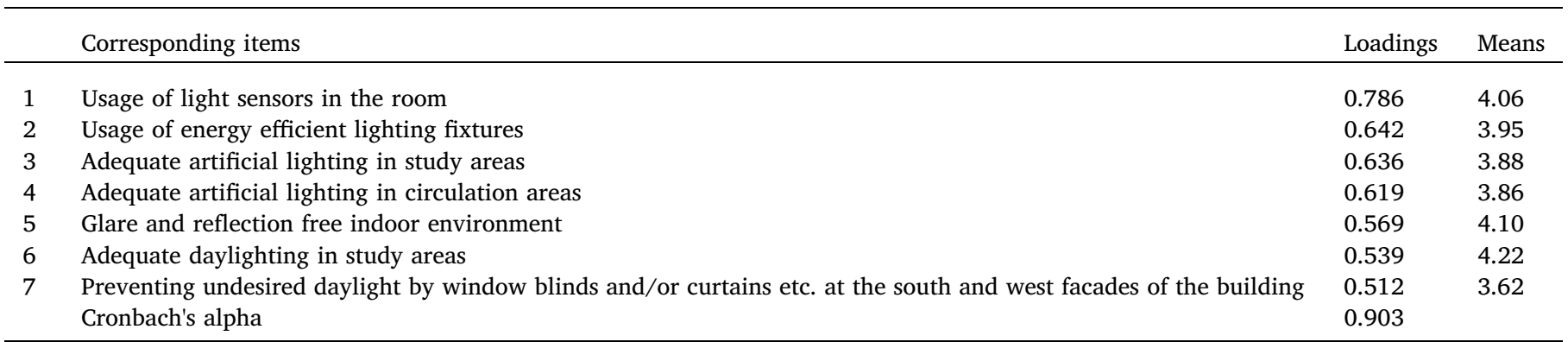

Table 2

Factor 2 'improved indoor air quality' and its corresponding item with their loadings.

\begin{tabular}{|c|c|c|c|}
\hline 1 & Adequate natural air ventilation provided from doors and windows. & 0.645 & 4.41 \\
\hline 2 & Adequate mechanical ventilation system for occupant comfort. & 0.617 & 4.41 \\
\hline 4 & Usage of toxic free materials in walls, floors, ceiling, floors etc. & 0.525 & 4.24 \\
\hline \multirow[t]{2}{*}{5} & Cleanness and maintenance of the room & 0.516 & 4.29 \\
\hline & Cronbach's alpha & 0.836 & \\
\hline
\end{tabular}

Table 3

Factor 3 'adequate thermal comfort' and its corresponding item with their loadings.

\begin{tabular}{|c|c|c|c|}
\hline 1 & Even heat distribution within the room & 0.656 & 4.09 \\
\hline 2 & Heating systems providing adequate thermal comfort for occupants & 0.631 & 4.19 \\
\hline \multirow[t]{2}{*}{4} & Efficiency of thermal insulation & 0.557 & 3.69 \\
\hline & Cronbach's alpha & 0.722 & \\
\hline
\end{tabular}

Table 4

Factor 4 'technology usage' and its corresponding item with their loadings.

\begin{tabular}{|c|c|c|c|}
\hline 1 & Availability electronic-only format & 0.721 & 4.15 \\
\hline 2 & Availability of energy efficient electrical office tools (computers, copying machines, printers etc.) & 0.648 & 4.01 \\
\hline \multirow[t]{2}{*}{4} & Availability of virtual bookshelf & 0.525 & 4.77 \\
\hline & Cronbach's alpha & 0.756 & \\
\hline
\end{tabular}

\section{References}

Aabø, S. (2005). The role and value of public libraries in the age of digital technologies. Journal of Librarianship and Information Science, 37(4), 205-211.

Ali, H. H., \& Al Nsairat, S. F. (2009). Developing a green building assessment tool for developing countries-Case of Jordan. Building and Environment, 44(5), 1053-1064.

Andaleed, S. S., \& Simmonds, P. L. (1998). Explaining user satisfaction with academic libraries: Strategic implications. March: College and Research Libraries, 156-167.

Antonelli, M. (2008). The green library movement: An overview and beyond, Electronic Green Journal 1 (27). Available online at http://repositories.cdlib.org/uclalib/egj/ vol1/iss27/art1/. [Accessed 9 March 2014].

Antonelli, M., \& McCullough, M. (Eds.), (2012). Greening libraries. Los Angeles: Library Juice Press.

Argyrous, G. (2005). Statistics for research. London: Sage Publications.

ASHRAE (2004). ANSI/ASHRAE standard 55-2004, thermal environmental conditions for human occupancy. Atlanta, GA: American Society of Heating, Refrigerating and AirConditioning Engineers.

Barki, H., \& Hartwick, J. (1989). Rethinking the concept of user involvement. MIS
Quarterly, 13(1), 53.

Bentler, P. M., \& Chou, C. (1987). Practical issues in structural modeling. Sociological Methods \& Research, 16(1), 78-117.

Bilkent University Library, Available online at http://library.bilkent.edu.tr [Accessed 19 July 2016].

Birkeland, J. (2002). Design for sustainability: A sourcebook of integrated, eco-logical solutions. London: Earthscan.

Blouin, F. X., Jr. (2010). Thoughts on special collections and our research communities. RBM: A Journal of Rare Books, Manuscripts, and Cultural Heritage, 11(1), 27.

Bougdah, H., \& Sharples, S. (2009). Environment, technology and sustainability. London: Taylor \& Francis.

Brodie, M. (2012). Building sustainable library at Macquarie University. Australian Academic and Research Libraries, 43(1), 4-16.

Brown, Z., Cole, R. J., Robinson, J., \& Dowlatabadi, H. (2010). Evaluating user experience in green buildings in relation to workplace culture and context. Facilities, 28(3/4), 225-238.

Building Research Establishment (BRE). Building research establishment environmental assessment method (BREEAM). (1982). available at http://www.breeam.com [Accessed 20 June 2014] . 
Cave, R. (1982). Rare book librarianship (2nd, revised ed.). London: Clive Bingley.

Chowdhury, G. (2010). Carbon footprint of the knowledge sector: What's the future? Journal of Documentation, 66(6), 934-946.

Curzon, S., \& Quinonez-Skinner, J. (2009). Academic libraries. Encyclopedia of Library and Information Sciences.. http://dx.doi.org/10.1081/E-ELIS3-120044525 [Accessed 1 September 2016].

Damodaran, L. (1996). User involvement in the systems design process-a practical guide for users. Behaviour \& Information Technology, 15(6), 363-377.

DeClercq, C. P., \& Cranz, G. (2014). Moving beyond seating-centered learning environments. The Journal of Academic Librarianship, 40(6), 574-584.

Douglas, J. (2006). Building adaptation. London: Routledge.

Duverger, P. (2012). Variety is the spice of innovation: Mediator factors in the service idea generation process. Creativity and Innovation Management, 21, 106-119.

Edward, B. W. (2011). Sustainability as a driving force in contemporary library design. Library Trends, 60(1), 190-214.

Gould, J. D., \& Lewis, C. (1985). Designing for usability: Key principles and what designers think. Communications of the ACM, 28(3), 300-311.

Green Building Council Australia. http://www.new.gbca.org.au/ [Accessed 20 June 2014].

Hardesty, L. (2011). The environmental sustainability of academic libraries. Library Issues, $32(1), 1-4$.

IFLA. IFLA rare book and special collections section guidelines for planning the digitization of rare book and manuscript collections. (2014). Available online at http://www.ifla.org/ files/assets/rare-books-and-manuscripts/rbms-guidelines/guidelines-for-planningdigitization.pdf [Accessed 9 May 2015] .

Ives, B., \& Olson, M. H. (1984). User involvement and MIS success: A review of research. Management Science, 30(5), 586-603.

Jankowska, M. A., \& Marcum, J. W. (2010). Sustainability challenge for academic libraries: Planning for the future. March, College and Research Libraries160-170.

Kilic, D. K., \& Hasirci, D. (2011). Daylighting concepts for university libraries and their influences on users' satisfaction. The Journal of Academic Librarianship, 37(6), 471-479.

Kujala, S. (2003). User involvement: A review of the benefits and challenges. Behaviour \& Information Technology, 22(1), 1-16.

LEED. For existing buildings. (2009). Available online at http://www.usgbc.org/resources/ leed-2009-existing-buildings-current-version [Accessed 1 March 2015] .
Little, G. (2012). A place of connection more than repository: Using technology in special collections. The Journal of Academic Librarianship, 38(3), 172-174.

Luther, M. B., \& Rajagopalan, P. (2014). Defining and developing an energy retrofitting approach. Journal of Green Building, 9(3), 151-162.

Mao, J., Vredenburg, K., Smith, P. W., \& Carey, T. (2005). The state of user-centered design practice. Communications of the ACM, 48(3), 105-109.

Michnik, K. (2015). Public libraries digital services and sustainability issues. The Bottom Line, 28(1/2), 34-43.

Nunnally, J. (1978). Psychometric theory. New York: McGraw-Hill.

Olsson, E. (2004). What active users and designers contribute in the design process. Interacting with Computers, 16(2), 377-401.

Pearson, D. (2010). Special collections in a digital future. Art Libraries Journal, 35(1), 13.

Regulation of Energy Performance in Buildings. available at http://www.resmigazete.gov.tr/ eskiler/2008/12/20081205-9.htm [Accessed 10 January 2014].

Sanders, E. B. N. (2002). From user-centered to participatory design approaches. Design and the Social Sciences: Making Connections, 1-8.

Sands, J. (2007). Sustainable library design. Santa Monica: Libris Design, 2007. Available online at www.librisdesign.org/docs/SustainableLibDesign.pdf [Accessed 7 February 2014].

Sesana, M. M., Grecchi, M., Salvalai, G., \& Rasica, C. (2016). Methodology of energy efficient building refurbishment: Application on two university campus-building case studies in Italy with engineering students. Journal of Building Engineering, 6, 54-64.

Shane, J. (2012). Positioning your library for solar (and financial) gain. Improving energy efficiency, lighting, and ventilation with primarily passive techniques. The Journal of Academic Librarianship, 38(2), 115-122.

United Nations Brundtland Commission. Report of the World Commission on Environment and Development: Our common future. (1987). available at http://www.un-documents.net/ our-common-future.pdf [Accessed 20 June 2014] .

US Green Building Council. Leadership in energy and environmental design (LEED). (2001). available at www.usgbc.org/ [Accessed 20 June 2014] .

Weiner, J., \& Boyden, L. (2001). Creating sustainable libraries. Library Journal, 126(20), 8-10.

Zhao, D., He, B., Johnson, C., \& Mou, B. (2015). Social problems of green buildings: From the humanistic needs to social acceptance. Renewable and Sustainable Energy Reviews, 51, 1594-1609. 